\title{
Leptin stimulates aromatase in the growth plate: limiting catch-up growth efficiency
}

\author{
Majdi Masarwi1,2, Raanan Shamir1,2,3, Moshe Phillip1,2,4 and Galia Gat-Yablonski1,2,4 \\ 1Sackler Faculty of Medicine, Tel Aviv University, Tel Aviv, Israel \\ ${ }^{2}$ Felsenstein Medical Research Center, Petach Tikva, Israel \\ IInstitute of Gastroenterology, Nutrition and Liver Diseases, Schneider Children's Medical Center of Israel, Petach Tikva, Israel \\ ${ }^{4}$ The Jesse $Z$ and Sara Lea Shafer Institute for Endocrinology and Diabetes, National Center for Childhood Diabetes, Schneider Children's Medical Center \\ of Israel, Petach Tikva, Israel \\ Correspondence should be addressed to G Gat-Yablonski: galiagy@post.tau.ac.il
}

\section{Abstract}

Catch-up growth (CUG) in childhood is defined as periods of growth acceleration, after the resolution of growth attenuation causes, bringing the children back to their original growth trajectory. Sometimes, however, CUG is incomplete, leading to permanent growth deficit and short stature. The aim of this study was to investigate the mechanisms that limit nutritional-CUG. Specifically, we focused on the crosstalk between leptin, increased by re-feeding, and sex hormones, which increase with age. In vivo studies were performed in young male Sprague Dawley rats fed ad libitum or subjected to $10 / 36$ days of $40 \%$ food restriction followed by 90-120 days of re-feeding. In vitro studies were performed on ATDC5 cells. Analyses of mRNA and protein levels were done using qPCR and Western blot, respectively. CUG was complete in body weight and humerus length in animals that were food-restricted for 10 days but not for those food-restricted for 36 days. In vitro studies showed that leptin significantly increased aromatase gene expression and protein level as well as the expression of estrogen and leptin receptors in a dose- and time-dependent manner. The effect of leptin on aromatase was direct and was mediated through the MAPK/Erk, STAT3 and PI3K pathways. The crosstalk between leptin and aromatase in the growth plate suggests that re-feeding during puberty may lead to increased estrogen level and activity, and consequently, irreversible premature epiphyseal growth plate closure. These results may have important implications for the development of novel treatment strategies for short stature in children.

\author{
Key Words \\ - catch-up growth (CUG) \\ - leptin \\ - aromatase \\ - growth plate \\ - ATDC5
}

Journal of Endocrinology (2018) 237, 229-242

\section{Introduction}

Temporary growth attenuation in children may be due to endocrinological, nutritional, medical or emotional disorders. Catch-up growth (CUG) is a phase of accelerated growth that follows the correction of these disorders, making it possible for the children to resume their preillness growth curve (Prader et al. 1963, Boersma et al. 2002). Occasionally, however, recovery is incomplete, leading to a permanent growth deficit and short stature. Therefore, means to increase the efficiency of this process is required.

The association between nutrition and linear growth in children is well accepted. The growth of the human skeleton requires many different nutritional factors for building materials and participation in regulatory 
processes (Gat-Yablonski \& De Luca 2017). To resume normal growth or initiate CUG, undernourished children must regain up to $85 \%$ of their weight for height (Kay's \& Hindmarsh 2006).

Long bones are formed through endochondral ossification wherein a cartilage template is formed by condensed mesenchymal cells and later replaced by bone tissue. The process of endochondral ossification starts with the axial proliferation of resting early chondrocytes located at the most epiphyseal end of the growth plate (GP), near the end of the long bones. The chondrocytes then align in columns (proliferation zone) parallel to the long axis of the bone and ultimately mature into hypertrophic chondrocytes (hypertrophic zone). The hypertrophic cells cease dividing, increase in volume by five- to tenfold and promote the deposition of components of the extracellular matrix and the secretion of matrix vesicles that contain matrix-processing enzymes and serve as centers of mineralization. Thereafter, the chondrocytes undergo either programmed cell death with calcification of the extracellular matrix or trans-differentiation to endochondral osteoblasts, switching from the synthesis of cartilage collagens (mostly type II and X) to the synthesis of type I collagen (Yang et al. 2014, Zhou et al. 2014). Blood vessels invade the tissue, and initiate the formation of bone, supplanting the cartilage. GP fusion occurs when the GP chondrocytes exhaust their proliferative potential in a process of senescence during puberty that is regulated by sex hormones. Senescence was shown to be accelerated by estrogen (Weise et al. 2001, Chagin et al. 2007, Nilsson et al. 2014).

There are multiple factors, both systemic and local, that coordinate and couple chondrocyte proliferation and differentiation at the GP. Many of them are affected by nutritional status, including growth hormone $(\mathrm{GH})$, insulin-like growth factor (IGF)-I, thyroid hormone, leptin, growth and differentiation factor 5 (Shtaif et al. 2015), corticosterone and sex hormones (Stevens \& Williams 1999, Chrysis et al. 2003).

Estrogen is the principal regulator of GP fusion in both males and females, as shown in studies of males with mutations in the genes encoding estrogen receptor $\alpha(E S R \alpha)$ (Smith et al. 1994) or aromatase (CYP19A1) (Carani et al. 1997), in addition to animal experiments (Chagin et al. 2007). In males, most estrogen is synthesized by peripheral tissues through local aromatization of circulating androgens. Aromatase catalyzes the rate-limiting step in the conversion of C19 androgens (androstenedione and testosterone) to C18 estrogenic steroids (estrone and estradiol). It is found in many tissues, including adipose tissue, brain, skin and bone (Sasano et al. 1997), and in GP chondrocytes (Oz et al. 2001, Eshet et al. 2004).

The aim of this study was to investigate the crosstalk between leptin, which is increased by re-feeding after food restriction (Pando et al. 2014), and sex hormones, which increase with age, in order to gain insight into the mechanism that limits nutritional-induced CUG. Experiments were performed in vivo, using a male Sprague Dawley rat model of food-restriction-induced growth attenuation followed by re-feeding, and in vitro, using chondrogenic ATDC5 cells.

\section{Materials and methods}

\section{In vivo studies}

All in vivo experiments were performed on pre-pubertal 24-day-old male Sprague-Dawley rats with an average weight of $50 \mathrm{~g}$ (Envigo, Ltd., Jerusalem, Israel), maintained under the same experimental conditions $\left(25 \pm 1^{\circ} \mathrm{C}\right.$, humidity $50 \pm 2 \%, 12 \mathrm{~h}$ light/dark cycle; lights off at 18:00 h) and fed the same commercial rat chow (Teklad Rodent Diet, 2018SC; WI, USA). The rats were housed separately in single cages to allow for monitoring of food intake. All experiments were approved by the Tel Aviv University Institutional Animal Care and Use Committee (committee protocol approval number: M-12096).

\section{Dietary manipulation}

At the age of 24 days, after three days of acclimatization to the solitary cages, the rats were randomly divided into two groups: a control group which had unlimited access to regular rat chow (AL group) and a restricted group fed $60 \%$ of the normal daily intake of the same chow for 10 days (Even-Zohar et al. 2008) or 36 days (Masarwi et al. 2016), depending on the specific experiment. The restricted group was further divided into two subgroups: continued restriction (RES group) or unrestricted re-feeding for various periods (CU group). Animals that were food-restricted for 10 days were followed for up to 120 days; those food-restricted for 36 days were followed for up to 90 days.

\section{Serum analysis}

At the end of the experiments, blood was collected by cardiac puncture, serum-separated and stored at $-70^{\circ} \mathrm{C}$. Serum levels of leptin and testosterone were determined using commercial kits: Mouse/Rat Leptin Quantikine ELISA Kit (cat. no. MOB00, R\&D Systems); Mouse/Rat 
Testosterone ELISA kit (cat. no. IB79174, Immuno-Biological Laboratories (IBL-America), Minneapolis, MN, USA).

\section{Histological staining and measurement of growth plate height}

The tibiae and humeri of each animal were carefully removed, cleaned and measured for length with a digital caliper. The tibiae were fixed in $4 \%$ neutral buffered formalin, decalcified with EDTA and $\mathrm{HCl}$ (Calci-Clear Rapid, cat. no. HS-105, National Diagnostics, Atlanta, GE, USA), dehydrated with a graded ethanol series (70, $95,100 \%$ ) and stabilized by two sequential changes of chloroform for paraffin embedding. Histological studies and GP height measurements were performed on paraffin sections of $6 \mu \mathrm{m}$, photographed and analyzed using Image-Pro software (version 4.5.1.22, Media Cybernetics, Rockville, MD, USA).

For immunohistochemistry, paraffin-embedded tissue sections were de-paraffinized in xylene, dehydrated in a graded series of ethanol and washed with PBS. Endogenous peroxidase was quenched using 3\% hydrogen peroxide in methanol for $30 \mathrm{~min}$. Nonspecific background was blocked by incubation with 10\% goat non-immune serum (cat. no. 95-6143B; Zymed). Sections were incubated with primary antibodies: 3 different anti-aromatase antibodies (cat. no. MCA2077s, Serotec, Oxford, UK; cat. no. ab18995, Abcam; cat. no. 3599-100, Biovision, Milpitas, CA, USA) and anti-leptin receptor (Ob-Rb; cat. no. ab177469, Abcam), followed by a biotinylated second antibody and streptavidin-peroxidase conjugated with aminoetyl carbazole substrate (Histostain-SP Kit, Zymed Laboratories, South San Francisco, CA, USA). An IgG isotype was used as a negative control.

\section{In vitro studies}

The chondrogenic ATDC5 cell line (ATCC) (Atsumi et al. 1990) was cultured in Dulbecco's Modified Eagle Medium/ Ham's-F12 (1:1 mixture, Gibco/Life Technologies, Thermo-Fisher Scientific) containing 5\% heat-inactivated fetal calf serum, 1\% L-glutamine and 1\% penicillin/ streptomycin (from Biological Industries, Beit HaEmek, Israel) at $37^{\circ} \mathrm{C}$ in a humidified atmosphere of $5 \% \mathrm{CO}_{2}$ in air. The cells were seeded at an initial cell density of $12 \times 10^{3}$ cells $/ \mathrm{cm}^{2}$ in a 6 -multiwell plate (Corning) as previously reported (Pando et al. 2014). The next day, the cells were induced to differentiate by the addition of insulin, transferrin and sodium selenite (ITS $0.2 \%$ ) (Sigma-Aldrich) for $4,7,14$ or 21 days to obtain cells at different stages of differentiation.
The cells were stimulated with recombinant murine leptin (Protein Laboratories Rehovot, Rehovot, Israel) in ITS-free medium (phenol-red-free DMEM/F-12; Gibco/Life Technologies, Thermo-Fisher Scientific) containing $0.5 \%$ charcoal stripped fetal bovine serum (Biological Industries) for $24 \mathrm{~h}$. Leptin stimulation was performed for $3,6,12$ and $24 \mathrm{~h}$.

\section{Western blot analysis}

ATDC5 cells were homogenized in a radio-immunoprecipitation assay buffer $(50 \mu \mathrm{L} /$ well of $20 \mathrm{mM}$ Tris- $\mathrm{HCl}$, pH 7.4, 0.15 M NaCl, 1\% NP-40, 0.25\% Na-deoxycholate) supplemented with a protease inhibitor cocktail (Roche) in a 1:12 ratio and with a phosphatase inhibitor cocktail (Roche) in a 1:10 ratio. The mixture was incubated on ice $(20 \mathrm{~min})$ followed by centrifugation at $21,000 \boldsymbol{g}$ for $5 \mathrm{~min}$. For each sample, $50 \mu \mathrm{g}$ of proteins was analyzed on $7.5 \%$ SDS-PAGE and transferred to a nitrocellulose blotting membrane (cat. no. 10600008, GE Healthcare). The nitrocellulose membranes were then incubated in TBS-T (10 mM Tris-HCl, $150 \mathrm{mM} \mathrm{NaCl,} \mathrm{0.1 \%} \mathrm{Tween} \mathrm{20)}$ with $5 \%$ skim milk for $1 \mathrm{~h}$ to block nonspecific binding. The membranes were incubated with primary antibodies against aromatase (cat. no. MCA2077s, Serotec), and leptin receptor (Ob-Rb) (cat. no. ab177469, Abcam), overnight at $4^{\circ} \mathrm{C}$, washed with TBS-T, incubated with a secondary fluorescent antibody (LI-COR Biosciences, Lincoln, NE, USA), decorated with IRDye for 1 hour and washed again. $\beta$-Actin served as the reference. Quantification was performed using the Odyssey Classic Imaging System with Odyssey Application Software (version 2.1.) (LI-COR Biosciences).

\section{Cell-signaling studies}

For the signal transduction studies, ATDC5 cells were incubated with the same ITS-free medium described earlier for $24 \mathrm{~h}$ and then treated for $1 \mathrm{~h}$ with specific inhibitors. Leptin was then added to the cells $(100 \mathrm{ng} / \mathrm{mL})$, the effect on phosphorylation was assayed after 1, 5, 15, 30 and $60 \mathrm{~min}$ (depending on the target) and the effect on aromatase expression was assayed after $6 \mathrm{~h}$. The following inhibitors were used (all from Abcam): mitogen-activated protein kinase (MAPK)/extracellular signal-regulated kinases (ERK1/2) (MEK1/2) inhibitor U0126 (cat. no. ab120241-5-B; $5 \mu \mathrm{M}$ or $20 \mu \mathrm{M}$ ); phosphoinositide 3-kinase (PI3K) inhibitor LY294002 (cat. no. ab120243-5-B, 5 $\mathrm{MM}$ or $10 \mu \mathrm{M})$ or Wortmannin $(10 \mu \mathrm{M})$; and signal transducer and activator of transcript (STAT)-3 inhibitor Stattic (cat no. $120952-10-\mathrm{B} ; 2.5 \mu \mathrm{M}$ or $5 \mu \mathrm{M}$ ). To follow the effect on phosphorylation, the following antibodies were used 
(all from Cell Signaling): anti-phospho ERK1/2 (cat. no. 4376) and rabbit monoclonal anti-total ERK1/2 (cat. no. 9102); anti-phospho Akt antibody (Ser473, cat. no. 4060) and rabbit monoclonal anti-total-Akt antibody (cat. no. 4691); anti-phospho STAT3 (anti-pTyr705, cat. no. 9131 and anti-pSer727, cat no. 9134); and rabbit monoclonal anti-total STAT3 (cat. no. 12640).

\section{RNA isolation}

Total RNA was extracted from ATDC5 cells using $1 \mathrm{~mL}$ TRIzol Reagent (Ambion/Life Technologies, Thermo-Fisher Scientific), and stored at $-70^{\circ} \mathrm{C}$. First-strand cDNA was synthesized using $2 \mu \mathrm{g}$ total RNA (ratio of $260 / 280 \geq 1.9$ ) as a template with the PrimeScript RT reagent Kit (Perfect Real Time, cat. No. RR037A, Clontech Laboratories, TaKaRa Bio) and the high capacity RNA to cDNA kit (cat. no. AB-4387406, Applied Biosystems).

\section{Real-time qPCR}

Quantitative real-time polymerase chain reaction (qPCR) was performed using TaqMan technology and commercially available FAM-labeled assays (all reagents were from Applied Biosystems): aromatase (Cyp19a1, Mm00484049_m1), Ob-Rb (Lepr, Mm01265583_m1), ER- $\alpha$ (Mm00433149_m1), collagen II (Mm01309565_m1) and collagen X (Mm00487041_m1); TATA-box binding protein (TBP, Mm00446973_m1) served as the endogenous control. TaqMan Fast Advanced Master Mix was used at a final reaction volume of $10 \mu \mathrm{L} /$ well $(20 \mu \mathrm{L} /$ well for aromatase and Ob-Rb) in 96-well plates. Reactions were performed in triplicate on cDNA using the StepOne Real-Time PCR system (version 2.2.2, Applied Biosystems). Cycling parameters were: $50^{\circ} \mathrm{C} * 2 \mathrm{~min}$, $95^{\circ} \mathrm{C} * 10 \mathrm{~min}$, then 50 cycles of $95^{\circ} \mathrm{C} * 15 \mathrm{~s}, 60^{\circ} \mathrm{C} * 1 \mathrm{~min}$.

The relative quantity of mRNA was first normalized to the endogenous reference TBP by subtracting the $C t$ of TBP from the $C t$ of the gene of interest to obtain $\Delta C t$. The $\Delta C t$ of the leptin-treated samples was compared with that of the control samples, and the difference was designated as $\Delta \Delta C t$. The fold change between the treated and control samples was then calculated as $2^{-\Delta \Delta C t}$.

\section{Luciferase assay}

Transient transfection experiments were done using the pGL3 vector expressing the human aromatase promoter II and I.3 sequence ligated to a firefly luciferase reporter gene. (The PGL3PII/I.3 plasmid was provided by Dr Kristy A Brown, Hudson Institute of Medical Research, Clayton, Australia.) The pRL-CMV-Renilla luciferase expression vector (Promega) served as a control. At $24 \mathrm{~h}$ after transfection, cells were serum-starved for $24 \mathrm{~h}$, followed by the addition of leptin for another $6 \mathrm{~h}$ (a total of $54 \mathrm{~h}$ ) and then harvested. The luciferase activity assay was performed using the Dual-Luciferase Reporter Assay system (Promega). Relative luciferase activity was calculated as the ratio of the Firefly luciferase activity to the Renilla luciferase activity and compared to cells transfected with the same vectors but not treated with leptin.

\section{Statistical analysis}

Data are presented as mean \pm s.D. The significance of differences between experimental groups was determined with one-way analysis of variance (ANOVA) with Tukey's post hoc test (multiple groups). Differences in weight were analyzed with ANOVA with repeated measures. Data were generated and analyzed with SPSS version 21 (IBM) software. Differences were considered statistically significant at $P<0.05$.

\section{Results}

In vivo studies

\section{Effect of food restriction on CUG}

Male Sprague Dawley rats (24 days) were subjected to 10 days of $40 \%$ food restriction followed by unrestricted re-feeding for 1, 2, 7 (Even-Zohar et al. 2008), 26, 60 or 120 days (CU group); complete CUG (bone length and body weight) was noted after 60 days of re-feeding (Supplementary Fig. 1, see section on supplementary data given at the end of this article). The control group of the 26-day study that was food-restricted for a total of 36 days showed increased accumulation of fat in the bone marrow (Supplementary Fig. 2).

We speculated that fat accumulation in the bones may indicate that the effect of malnutrition on bones was already irreversible; therefore, in the next experiments, 24-day-old rats were subjected to 36 days of $40 \%$ food restriction followed by unrestricted re-feeding for 24 days or 90 days (CU group). Their average body weights are presented in Fig. 1A and C. The body weight of the re-fed animals increased, but remained significantly lower than that of control rats fed ad libitum for the whole experiment (AL group) (Fig. 1C, $P<0.0001$ ). Re-feeding also led to an increase in the weight of the internal organs, but values remained significantly lower than those of the controls at all time points checked. The growth rate was different for each organ (Fig. 1B). After 90 days of re-feeding, the 
A
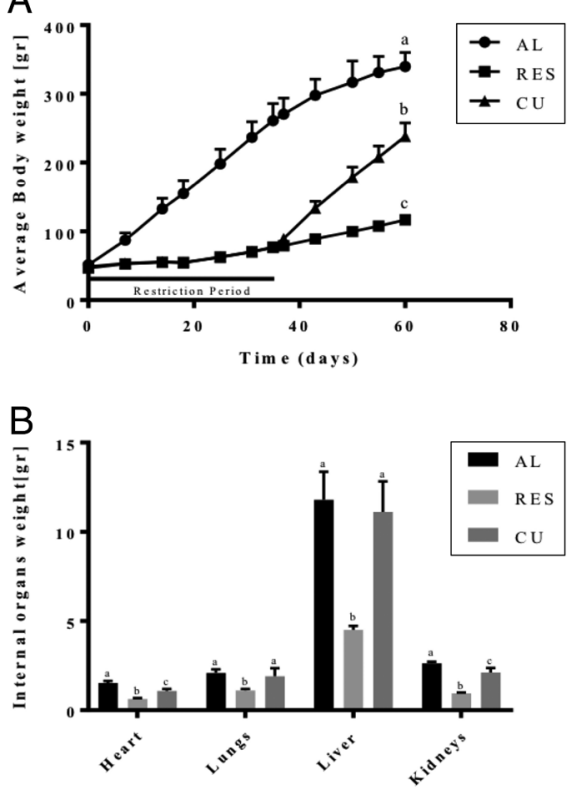

C
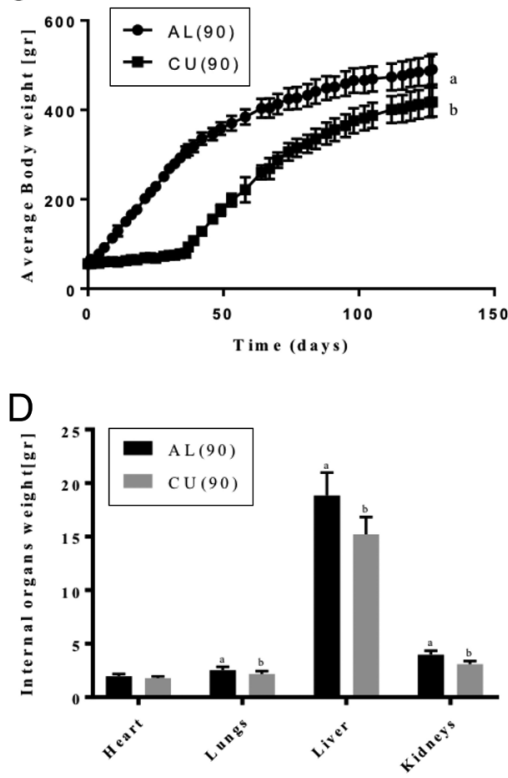

Figure 1

Effect of food restriction and re-feeding on body and internal organ weight. Body weight was monitored throughout the experiment. (A) Body weight and (B) internal organ weight of rats subjected to 36 days of food restriction followed by 24 days of re-feeding. Data were analyzed by one-way ANOVA. (C) Body weight and (D) internal organ weight of rats subjected to 36 days of food restriction followed by 90 days of re-feeding. Data were analyzed by $t$-test. Superscripts within the graphs designate significant differences at $P<0.05$; curves/columns marked with the same letter did not differ significantly. AL - rats fed ad libitum (control group); RES - food-restricted group; CU catch-up group. lungs, liver and kidneys weighed significantly less in the $\mathrm{CU}$ than the AL group (Fig. 1D), but the heart weighed only slightly less.

The length of the humerus was significantly lower in the CU than in the AL group after both 24 days and 90 days of re-feeding (Fig. 2A and C). The height of the GP was significantly greater in the CU than in the AL group after 24 days (Fig. 2B, $P<0.0001$ ), but at 90 days, there was no significant between-group difference (Fig. 2D, $P=0.1$ ), probably reflecting the age-related shrinkage of the GP.

\section{Effect of sex hormones on CUG}

The inhibitory effect of estrogen on GP growth is well known (Chagin et al. 2007, Nilsson et al. 2014). As the animals in the AL and CU groups were of the same age, we were able to investigate whether the nutritional manipulation stimulated estrogen production, thereby leading to premature cessation of growth. Our earlier studies in similar models showed that leptin is significantly affected by nutritional manipulation: its level was significantly reduced in food-restricted rats and increased rapidly already after 1 day of re-feeding (Pando et al. 2014). In the present experiments, leptin and testosterone showed a similar pattern of secretion. Mean leptin levels were $3.1 \pm 1.44 \mathrm{ng} / \mathrm{mL}$ in the AL group, $0.47 \pm 0.28 \mathrm{ng} / \mathrm{mL}$ in the RES group (food-restricted for 36 days) and $2.3 \pm 0.83 \mathrm{ng} / \mathrm{mL}$ in the CU group (re-fed for 1 day). Corresponding testosterone levels were $1.81 \pm 0.51$, $0.42 \pm 0.1$ and $1.47 \pm 0.96 \mathrm{ng} / \mathrm{mL}$. For both factors, there was a significant difference between the RES and AL groups $(P<0.05)$ but not between the CU and AL groups.

\section{Detection of leptin receptor and aromatase in the growth plate}

Immunohistochemistry staining (Fig. 3) showed the presence of both aromatase (Fig. 3A, B and C), and the long form of leptin receptor (Ob-Rb, Fig. 3D, E and F) in the GP of all groups of rats. Aromatase was detected mostly in the resting zone (Fig. 3A, B and C), and $\mathrm{Ob}-\mathrm{Rb}$
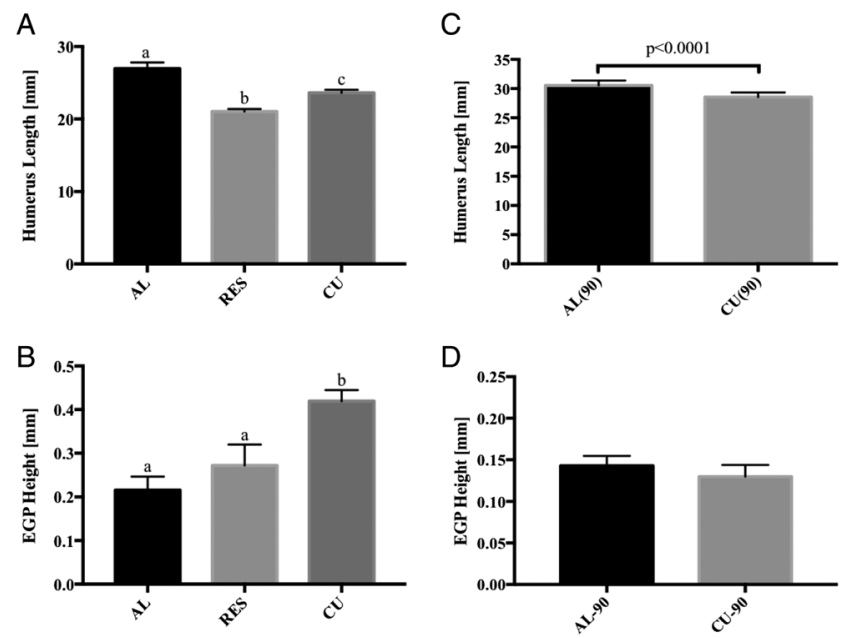

Figure 2

Effect of re-feeding on humerus length and growth plate height. (A) Humerus length and (B) growth plate (EGP) height in rats subjected to food restriction for 36 days followed by 24 days of re-feeding. Data were analyzed by one-way ANOVA. (C) Humerus length and (D) EGP height in rats subjected to food restriction for 36 days followed by 90 days of re-feeding. Data were analyzed by $t$-test. Superscripts within the graphs designate significant differences at $P<0.05$; columns marked with the same letter did not differ significantly. AL - rats fed ad libitum (control group); RES - food-restricted group; CU - catch-up group. 

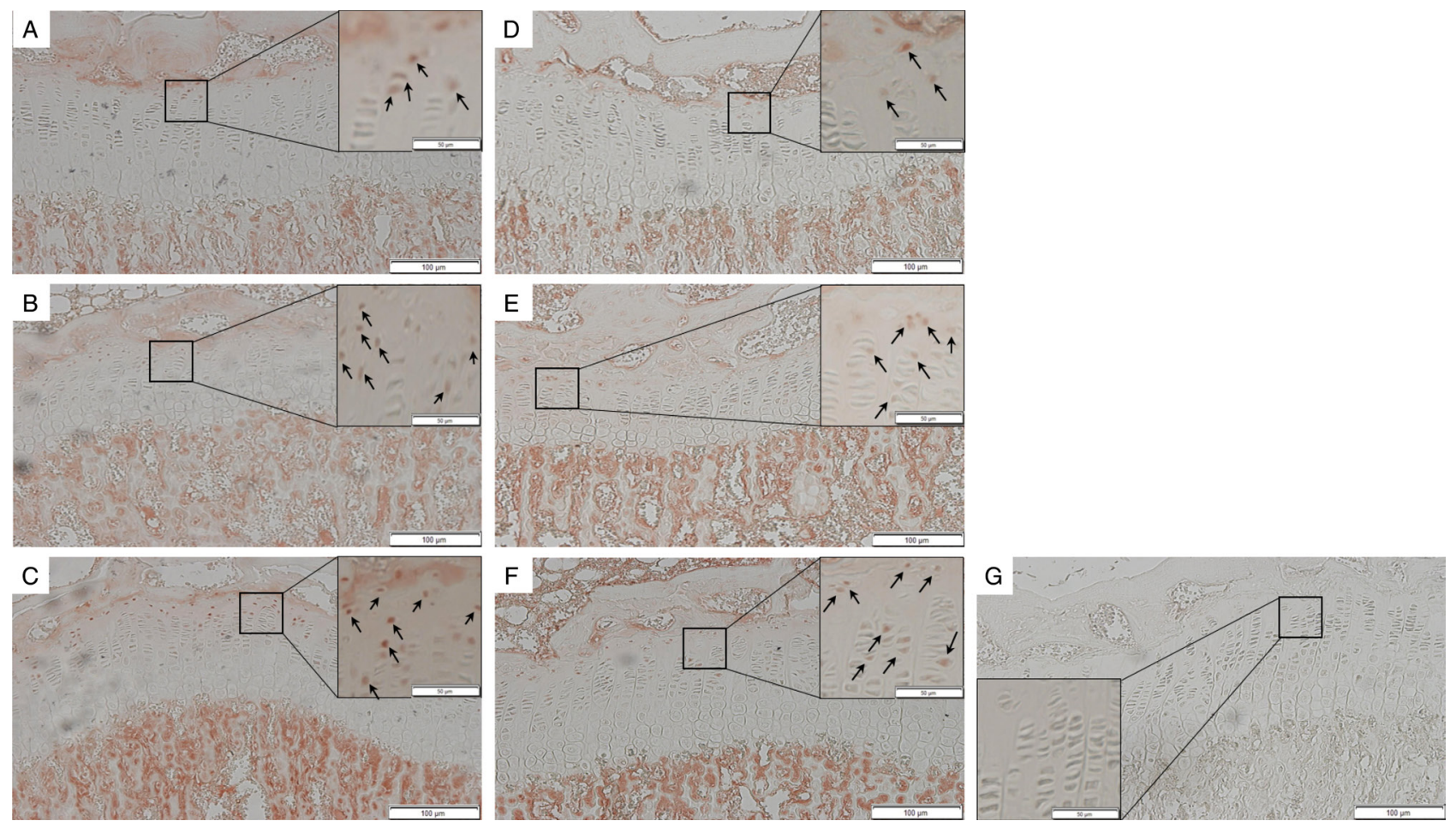

Figure 3

(Revised version): immunohistochemistry of aromatase enzyme and the long form of leptin receptor (Ob-Rb) in the humeral growth plate. Animals were fed ad libitum (AL) or food-restricted (RES), or food-restricted and then re-fed for 1 day (CU). All animals were killed at the same day. Aromatase-(A) rats fed ad libitum, (B) rats food-restricted throughout the experiment, (C) rats food-restricted followed by re-feeding stained with anti-aromatase antibody. Staining is located mainly in the resting zone in the AL and RES groups, whereas in the CU group, resting and proliferating chondrocytes were stained (arrows). Ob-Rb-(D) rats fed ad libitum, (E) rats food-restricted throughout the experiment, (F) rats food-restricted followed by re-feeding stained with anti-Ob-Rb antibody. (G) Negative control. In all groups, staining is located mainly in the resting and proliferating zones (arrows). Insets in all figures are of the same sections photographed with higher magnification (×20). A full color version of this figure is available at https://doi.org/10.1530/JOE-18-0028.

(Fig. 3D, E and F) was detected in both the resting and proliferative zones. In sections taken from RES animals, we noted a significant reduction in the level of $\mathrm{Ob}-\mathrm{Rb}$ during food restriction, followed by a rapid increase at 1 day of re-feeding mainly in the proliferative zone. The level of aromatase was very low in the sections of the control groups, with a slight increase in sections of the RES group and a marked increase in sections taken form the CU groups, in both the resting and proliferative zones. Similar results for aromatase were obtained when realtime PCR was performed on total RNA extracted from the GP (data not shown).

\section{In vitro studies}

\section{Effect of leptin on aromatase gene expression}

Although leptin was found to significantly increase aromatase gene expression and protein level in other cell types (Catalano et al. 2003), its effect on aromatase in chondrocytes is unknown. As the expression of both $\mathrm{Ob}-\mathrm{Rb}$ and aromatase was mostly confined to the resting and proliferative zones of the GP, we performed our studies on ATDC5 cells at their early differentiation stages.

Cells were grown for 4 or 14 days, serum-depleted for $24 \mathrm{~h}$, and then treated with leptin $(100 \mathrm{ng} / \mathrm{mL})$ for different time periods (Fig. 4A). The results showed that leptin stimulated the expression of aromatase mRNA in a time-dependent manner. A tendency to increase in aromatase mRNA was detected after $3 \mathrm{~h}$ of leptin treatment $(P=0.06)$, and a significant peak was noted at $6 \mathrm{~h}(P<0.01)$. Accordingly, for the dose-response study, cells grown for 4 days were similarly treated with leptin at different concentrations for $6 \mathrm{~h}$. As shown in Fig. 4B, the expression of aromatase followed a bell-shaped curve that peaked at $100 \mathrm{ng} / \mathrm{mL}$ leptin $(P=0.015)$.

\section{Effect on leptin receptor and estrogen receptor alpha expression}

We next studied the effect of leptin on the expression of $\mathrm{Ob}-\mathrm{Rb}$ and estrogen receptor alpha $(\mathrm{Er}-\alpha)$. Leptin $(100 \mathrm{ng} / \mathrm{mL})$ increased $\mathrm{Ob}-\mathrm{Rb}$ gene expression after $3 \mathrm{~h}$ $(P=0.043)$ and $6 \mathrm{~h}(P=0.007)$ of incubation (Fig. 5A), 
A

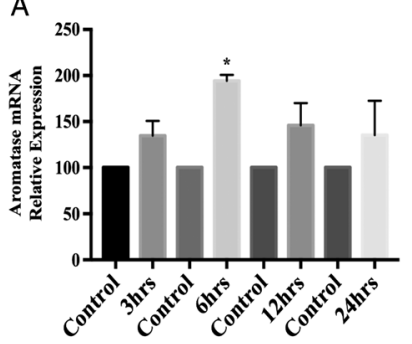

B

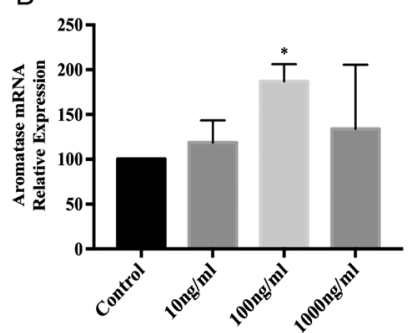

Figure 4

Effect of leptin on aromatase mRNA expression. ATDC5 cells were cultured in DMEM/F12 containing 5\% FCS and ITS for 4 days. (A) Cells incubated with or without (control) $100 \mathrm{ng} / \mathrm{mL}$ leptin for $3,6,12$ and $24 \mathrm{~h}$. (B) Cells treated with leptin at 0,10,100 and $1000 \mathrm{ng} / \mathrm{mL}$ for $6 \mathrm{~h}$. Aromatase gene expression was analyzed by $\mathrm{QPCR}$, normalized against TBP and compared to the control group. Data represent the mean ( \pm S.D.) value of triplicate samples in three independent experiments.

whereas the expression of ER- $\alpha$ significantly increased after $6 \mathrm{~h}$ of leptin incubation (Fig. 5B; $P<0.001$ ).

\section{Effect of leptin on aromatase gene expression and protein levels at 14 days of ATDC5 differentiation}

Western blot analysis of aromatase was unsuccessful when performed after 4 days of differentiation owing to its very low level of expression. However, at 14 days of differentiation, the protein level could be reliably detected. In cells serum-starved for $24 \mathrm{~h}, 48 \mathrm{~h}$ of treatment with $100 \mathrm{ng} / \mathrm{mL}$ leptin significantly increased both aromatase gene expression (Fig. 6A) and protein levels (Fig. 6B and C).

\section{Effect of leptin on the activity of the human aromatase promoter PII/PI.3}

We next investigated the activity of the aromatase promoter PII/PI.3 in ATDC5 cells treated with $100 \mathrm{ng} / \mathrm{mL}$ leptin. Analysis with the luciferase reporter assay showed
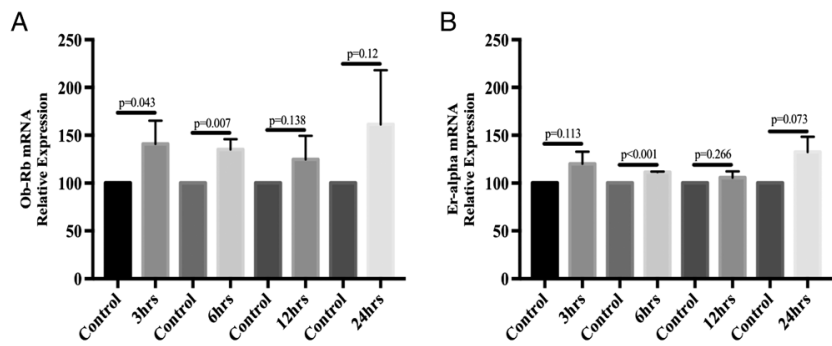

Figure 5

Effect of leptin on gene expression of the long form of leptin receptor $(\mathrm{Ob}-\mathrm{Rb})$ and estrogen receptor alpha (Er- $\alpha)$. ATDC5 cells were treated with $100 \mathrm{ng} / \mathrm{mL}$ leptin for 3, 6, 12 and $24 \mathrm{~h}$. (A) Expression of Ob-Rb. (B) Expression of Er- $\alpha$. Gene expression was analyzed by qPCR, normalized against TBP and compared to the control group. Data represent the mean ( \pm S.D.) value of triplicate samples in three independent experiments.
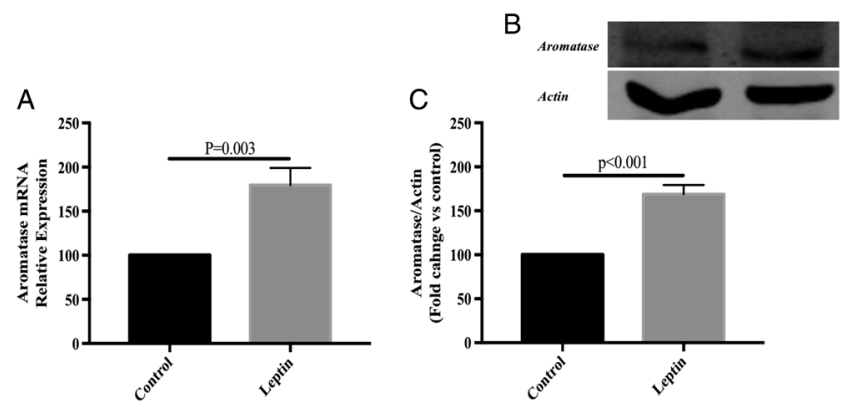

Figure 6

qPCR analysis and Western blot of aromatase expression in ATDC5 cells. Cells were cultured in DMEM/F12 containing 5\% FCS and ITS for 14 days, treated overnight with ITS-free medium containing $0.5 \% \mathrm{FCS}$, and incubated with $100 \mathrm{ng} / \mathrm{mL}$ leptin for $48 \mathrm{~h}$. (A) Aromatase mRNA expression. Gene expression was analyzed by $\mathrm{qPCR}$, normalized against TBP and compared to the control group. (B) Representative Western blot of aromatase. (C) Western-blot-normalized data. Data represent the mean ( \pm s.D.) value of triplicate samples in three independent experiments.

that leptin significantly increased aromatase promoter activity after $6 \mathrm{~h}$ of incubation (Fig. 7).

\section{Mechanism of leptin stimulation of aromatase gene expression}

We have previously shown that leptin exerts its biological action by binding to and activating Ob-Rb, in both GP chondrocytes and ATDC5 cell (Gat-Yablonski et al. 2004, Ben-Eliezer et al. 2007). Ob-Rb activates several classical signal transduction pathways: MAPK (MEK1/2) cascade via ERK1/2; STAT-3 and PI3K/Akt pathways. To assess which of these is activated by leptin in ATDC 5 cells and therefore important for leptin-induced aromatase expression, we systematically assessed their phosphorylation status. As shown in Figs 8, 9 and 10, leptin enhanced the phosphorylation of ERK1/2, STAT3 and Akt in a timedependent manner. Time-course experiments revealed that the phosphorylation of ERK1/2, STAT3 (Tyr705 and Ser727) and Akt was maximal after 1-5 min of leptin treatment and declined thereafter.

Next, we used specific inhibitors to delineate the role of each pathway in leptin-induced aromatase expression. U0126, the inhibitor of MEK1/2, suppressed the effect of leptin on ERK1/2 phosphorylation, as well as the effect of leptin on aromatase expression, in a dose-dependent manner (Fig. 8B). Leptin stimulated STAT3 (Fig. 9A) and Akt phosphorylation (Fig. 10A); pretreatment with Stattic and LY294002 profoundly reduced STAT3 (Tyr705 only) (Fig. 9B) and Akt (Fig. 10B) phosphorylation, respectively. Both STAT3 and PI3K inhibitors significantly reduced aromatase mRNA expression (Figs 9B and 10B, respectively). 


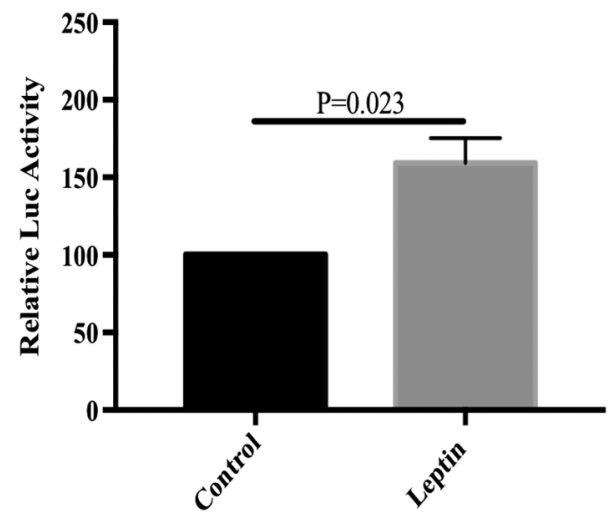

Figure 7

Effect of leptin on aromatase promoters PII/PI.3. ATDC5 cells were cultured in DMEM/F12 containing 5\% FCS and ITS for 4 days. The cells were transiently transfected with pGL3 vector expressing the human aromatase promoter II and I.3 sequence ligated to a firefly luciferase reporter gene, together with pRL-CMV-Renilla luciferase expression vector. At $24 \mathrm{~h}$ after transfection, the cells were serum-starved for $24 \mathrm{~h}$ and leptin was added for an additional $6 \mathrm{~h}$. The relative luciferase activity was calculated as the ratio of the firefly luciferase activity to the Renilla luciferase activity and compared to cells transfected with the same vectors but not treated with leptin. Data represent the mean ( \pm S.D.) values of triplicate samples in three independent experiments.

\section{Discussion}

Growth inhibition is common during childhood and may occur repeatedly, and each episode is usually followed by CUG. However, when the growth arrest is prolonged, and when close to completion of puberty, CUG may be incomplete, leading to a permanent growth deficit. The clinical toolbox for treating children with short stature is very limited, and identifying the mechanisms limiting CUG may have important implications for the development of novel means to improve height.

In this study, we specifically examined the crosstalk between leptin and sex hormones; we showed that leptin, increased with re-feeding, stimulates the activity of aromatase and together with the increase in testosterone by re-feeding and age, may be responsible for premature GP shrinkage and incomplete CUG. We have shown in vitro in ATDC5 cells that leptin induction of aromatase gene expression and protein levels occurred in a time- and dose-dependent manner via activation of the canonical signal transduction pathways, MAPK, STAT3 and PI3K.

The finding that leptin stimulates aromatase expression is not new (studies were done in endometrial fibroblasts (Liu et al. 2013), luteinized granulosa cells (Kitawaki et al. 1999) and MCF-7 breast cancer cells (Catalano et al. 2003)). Aromatase expression was reported in human mesenchymal stem cells of bone marrow (Heim et al. 2004) which can differentiate into osteoblasts, adipocytes and chondrocytes (Pittenger et al. 1999). Leptin plus vitamin $\mathrm{D} 1,25(\mathrm{OH})_{2} \mathrm{D}_{3}$ stimulated aromatase activity in the osteogenic lineage (Pino et al. 2006). However, to the best of our knowledge, it has never before been shown in chondrocytes.

Estrogen is responsible for both the growth spurt and GP fusion in both sexes (Cutler 1997, Stevens \& Williams 1999). The process of GP fusion is associated with senescence, manifested by a decline in the proliferative capacity of the resting chondrocytes with age (Schrier et al. 2006) and culminating in growth cessation. Studies in juvenile ovariectomized female rabbits showed that

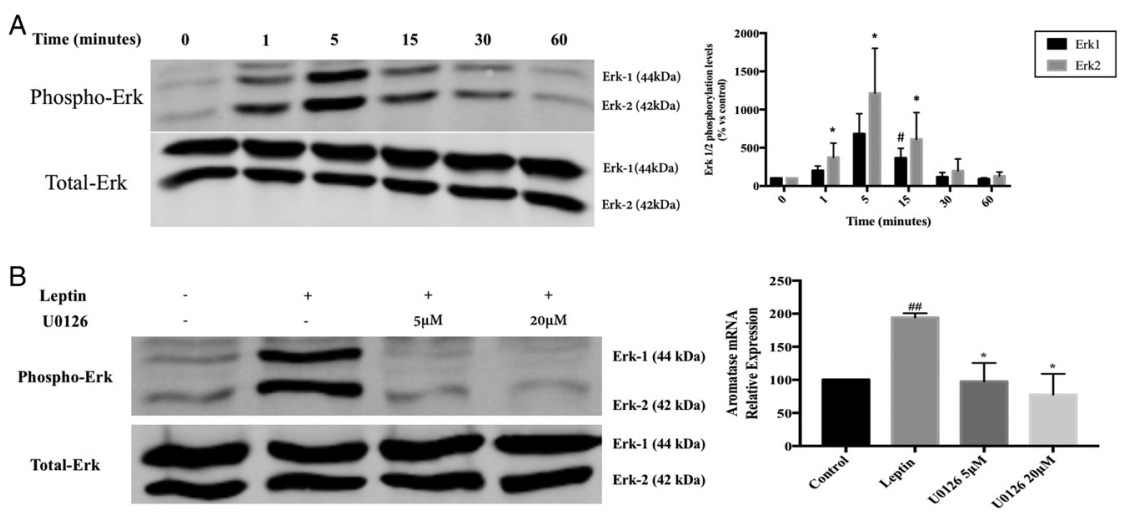

\section{Figure 8}

Leptin stimulation of aromatase expression-role of MAPK signaling pathway (ERK1/2). ATDC5 cells were cultured in DMEM/F12 containing 5\% FBS and ITS for 4 days. Cells were treated overnight with ITS-free medium containing $0.5 \%$ FCS. (A) Cells treated with $100 \mathrm{ng} / \mathrm{mL}$ leptin for the indicated times. The left panel shows a representative Western blot; the right panel shows the normalized data. (B) Cells treated with the MEK $1 / 2$ inhibitor U0126 $(5 \mu \mathrm{M}$ and $20 \mu \mathrm{M})$ for $60 \mathrm{~min}$ before the addition of $100 \mathrm{ng} / \mathrm{mL}$ leptin for $5 \mathrm{~min}$. P-ERK1/2 and total ERK1/2 protein levels were analyzed by Western blot. The left panel shows a representative Western blot; the right panel shows the effect on aromatase expression. Data represent the mean ( \pm S.D.) values of triplicate samples in three independent experiments. Columns marked with octothorpe (\#, ERK1) and asterisk (*, ERK2) are significantly different compared to baseline. http://joe.endocrinology-journals.org https://doi.org/10.1530/JOE-18-0028
() 2018 Society for Endocrinology Published by Bioscientifica Ltd. Printed in Great Britain 


\begin{tabular}{l|l|l|l|l|}
$\begin{array}{l}\text { Journal of } \\
\text { Endocrinology }\end{array}$ & M Masarwi et al. & $\begin{array}{l}\text { Leptin stimulates aromatase in } \\
\text { the EGP }\end{array}$ & $\mathbf{2 3 7 : 3}$ & $\mathbf{2 3 7}$
\end{tabular}

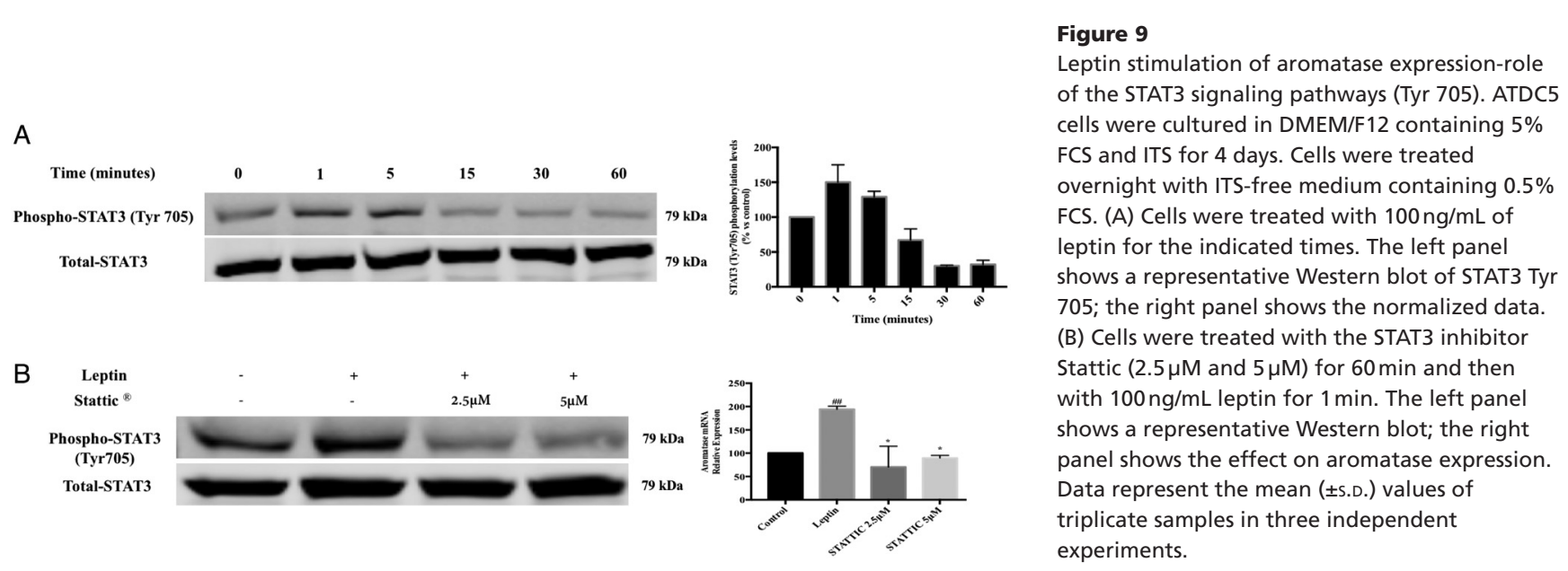

changes in estrogen level were associated with tibial chondrocyte proliferation rate, GP height, number of proliferative chondrocytes, number and size of hypertrophic chondrocytes and column density (Weise et al. 2001, Nilsson et al. 2014).

Sexually mature men with tall stature and unfused epiphyses have been reported in the literature. One such case had autosomal recessive inherited mutation in ER-alpha (Smith et al. 1994), and several others had mutations in CYP19A1 encoding aromatase (Belgorosky et al. 2009). These findings emphasized the importance of estrogen and estrogen signals in GP maturation and fusion in human males (Attie et al. 1990) and has led the way to the treatment of short stature using aromatase inhibitors (AI). Accordingly, we previously reported that applying the AI Letrozole to young male mice led to a significant increase in body weight, tail and tibial length in association with a marked increase in GP height (Eshet et al. 2004). Aromatase was expressed mainly in the hypertrophic and pre-hypertrophic chondrocytes of the GP, and slightly in the proliferative and resting chondrocytes. By contrast, in the present study, we found that aromatase was expressed mainly in the resting and proliferating GP chondrocytes. This discrepancy in localization is due to the different ages of the animals in the two studies (Supplementary Fig. 3).

Treatment of young boys with growth failure using AI, alone (Hero et al. 2005) or in combination with testosterone (Wickman et al. 2001), or GH (in GH-deficient patients) delayed GP closure, thereby increasing height potential. In a study of Finnish adolescent boys with constitutional growth and puberty delay, AI were used to increase adult height (Wickman et al. 2001). Later, other studies confirmed that the treatment of GH-deficient male adolescents with AI increased height (by $6.7 \mathrm{~cm}$ after 36 months) compared to treatment with GH alone (Mauras et al. 2008), with a significant delay in the tempo of bone age acceleration and lower estrogen levels in treated boys. Nevertheless, the clinical use of AI is still limited due to
A
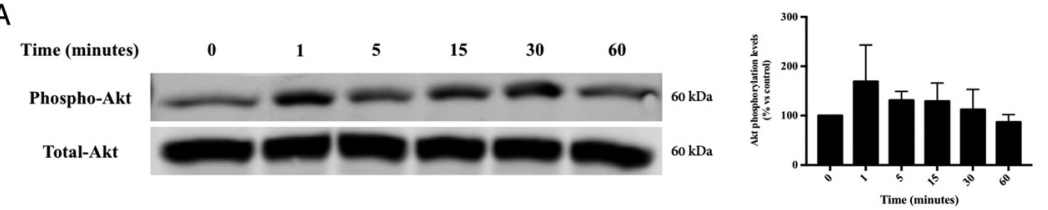

B Leptin

Phospho-Akt

Total-Akt
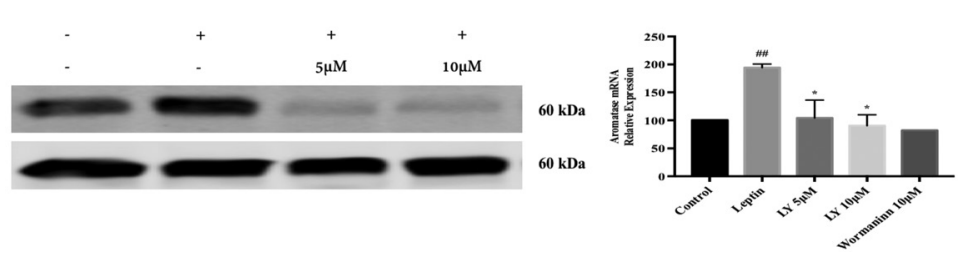

\section{Figure 10}

Leptin stimulation of aromatase expression-role of the PI3K signaling pathway. ATDC5 cells were cultured in DMEM/F12 containing $5 \%$ FCS and ITS for 4 days. Cells were treated overnight with ITS-free medium containing $0.5 \%$ FCS. (A) Cells were treated with $100 \mathrm{ng} / \mathrm{mL}$ of leptin for the indicated times. The left panel shows a representative Western blot; the right panel shows the normalized data. (B) Cells were treated with the PI3K inhibitors LY294002 (5 $\mathrm{MM}$ and $10 \mu \mathrm{M})$ and Wortmannin $(10 \mu \mathrm{M})$ for $60 \mathrm{~min}$ and then $100 \mathrm{ng} / \mathrm{mL}$ leptin for $1 \mathrm{~min}$. P-Akt and total Akt protein levels were analyzed by Western blot. The left panel shows a representative Western blot; the right panel shows the normalized data. Data represent the mean ( \pm S.D.) value of triplicate samples in three independent experiments. http://joe.endocrinology-journals.org https://doi.org/10.1530/JOE-18-0028
() 2018 Society for Endocrinology Published by Bioscientifica Ltd.
Printed in Great Britain 
concerns about an increased risk of vertebral deformities, decreased levels of high-density lipoprotein cholesterol and increased erythrocytosis (Wit et al. 2011).

Our group and others have extensively studied the role of leptin in regulating growth (Gat-Yablonski \& Phillip 2008, Turner et al. 2013). The present study shows that leptin can also regulate growth by stimulating aromatase in the presence of testosterone. Leptin, encoded by the obese $(\mathrm{Ob})$ gene, is produced and secreted mostly by adipose tissue, but also by other tissues such as fetal bone and cartilage (Kishida et al. 2005), and primary cultures of human osteoblasts (Reseland et al. 2001). Studies in humans have shown that leptin deficiency leads to developmental abnormalities of the skeleton and advanced bone age (Farooqi et al. 1999). We have previously shown that cultured mice mandibular condyles express Ob-R, and adding leptin to the culture increased mandibular condyle proliferation and differentiation (Maor et al. 2002). In a later study, leptin was found to significantly increase tibial length in normal mice compared to pair-fed control mice, probably acting through the parathyroidhormone-related protein (PTHrP)/Indian hedgehog (Ihh) loop (Gat-Yablonski et al. 2007). Furthermore, the addition of leptin to ATDC5 cells increased their differentiation, as manifested by an increased expression of type X collagen, a unique marker of hypertrophic chondrocytes (Kishida et al. 2005, Ben-Eliezer et al. 2007). Leptin also enhanced chondrocyte proliferation and differentiation in the early stage in cultured chondrocytes derived from rabbit ribs (Nakajima et al. 2003).

Our finding that $\mathrm{Ob}-\mathrm{R}$ is expressed mainly in resting and proliferating GP chondrocytes contrasts with the report of Kishida et al. (2005) of Ob-R expression in the terminal hypertrophic chondrocytes. This discrepancy may be due to differences in the animal model used (rats vs mice) or the different ages of the animals (61 days in our study vs 28 days in the earlier study). The immunohistochemistry staining revealed that like Ob-Rb, aromatase was expressed in resting and proliferating chondrocytes of the GP. This finding indicates that local interactions between aromatase and leptin in the resting and proliferation zones are indeed feasible.

Leptin binding to the $\mathrm{Ob}-\mathrm{Rb}$ receptor activates the MAPK, STAT3 and PI3K signaling pathways (Hegyi et al. 2004, Ben-Eliezer et al. 2007, Yang \& Barouch 2007). MAPK, present in all eukaryotic cells, coordinately regulates cellular growth and differentiation as well as chondrocyte differentiation (Phornphutkul et al. 2006). In the present study, leptin was found to stimulate the phosphorylation of ERK1/2, and this effect, along with the effect of leptin on aromatase, was abrogated with pretreatment with a MEK-specific inhibitor (U0126). These results are consistent with those of a previous study showing that leptin induced aromatase expression and activity in MCF7 cells through ERK1/2 signaling (Catalano et al. 2003).

STATs play an important role in mediating leptinregulated gene transcription (Yang \& Barouch 2007). In chondrocytes, previous studies showed that leptin regulates the expression of matrix metalloproteinases through STAT3 and STAT5 signals (Hui et al. 2012), with STAT3 increasing the expression of multiple genes in chondrocyte cells, such as type $X$ collagen and Frizzled receptors (Ben-Eliezer et al. 2007, Ohba et al. 2010). STAT3 phosphorylation is important on both Tyr705 and on Ser727 (Aggarwal et al. 2009, Sakaguchi et al. 2012), as Ser727 phosphorylation regulates STAT3 nuclear translocation and cell survival (Sakaguchi et al. 2012). In the present study, leptin increased STAT3 phosphorylation on both tyrosine 705 (Fig. 9A) and serine 727 (data not shown). Blocking STAT3 signaling using the selective STAT3 inhibitor Stattic significantly reduced both the phosphorylation of STAT3, and aromatase mRNA expression, pointing to the biological significance of STAT3 signaling in regulating aromatase expression (Stattic is specific to Tyr 705; it was shown to inhibit STAT3 dimerization and translocation to the nucleus (Schust et al.)).

PI3K is a family of enzymes involved in cellular functions, such as cell growth, proliferation, differentiation and survival and intracellular trafficking. PI3K/Akt is considered the canonical PI3K signaling pathway (Carracedo \& Pandolfi 2008) and plays a role in anabolic and catabolic processes in cartilage in response to IGF-I (Starkman et al. 2005), leptin (Hui et al. 2012) and other cytokines (Wegiel et al. 2008). PI3K/Akt induced the expansion of chondrocyte proliferation and blocked hypertrophic chondrocyte differentiation, perhaps as a consequence of the suppression of Runx 2 expression (Kita et al. 2008). Consistent with other studies, we showed that leptin increased PI3K phosphorylation in a timedependent manner. Adding LY294002 or Wortmannin to ATDC5 cells significantly reduced aromatase expression, and LY294002 significantly reduced Akt phosphorylation.

ADTC5 cells treated with leptin showed an increase in the gene expressions of leptin receptor, ER- $\alpha$ and aromatase. Similar results were previously shown by Wang et al. (2012b) who showed in ATDC5 cells that leptin increased estrogen receptor mRNA expression and protein levels in a dose-dependent manner by activating 
ERK1/2, and that estrogen significantly up-regulated Ob-R protein and mRNA levels (Wang et al. 2012a).

Our results are consistent with previous data showing that aromatase expression is regulated through MAPK (Erk1/2, P38 and JNK) and PI3K/Akt signaling in adipose tissue (Tan et al. 2015) and through STAT3, MAPK and PI3k/Akt in breast cancer cells (Catalano et al. 2003, Phuong et al. 2014). The organization of the aromatase first exon is complex and leads to 9 alternative tissue specific versions, while the coding region and the protein expressed are always the same (Harada et al. 1993). Aromatase promoters I.3, PII, I.4 and I.6 are expressed in bone and chondrocyte cells (Enjuanes et al. 2005, Jeong et al. 2010). The regulatory elements contain binding sites for c-Fos and c-Jun (AP-1) that can be activated by MAPK signaling, a binding site for STAT3 and others. In the present study, treatment of ATDC5 cells with leptin $(100 \mathrm{ng} / \mathrm{mL})$ significantly increased aromatase mRNA through MAPK Erk1/2 (Fig. 8), P38 and JNK (data not shown), STAT3 (Fig. 9) and PI3K/Akt (Fig. 10). Inhibiting every pathway alone was sufficient to significantly reduce aromatase expression.

Obesity is associated with high serum leptin levels due to the increase in adipose tissue concomitant with central resistance to circulating leptin. The differential sensitivity to the central effect of leptin (at the hypothalamus) (Jung \& Kim 2013), and the peripheral effect of leptin (at the GP) (Maor et al. 2002, Kishida et al. 2005) may explain the accelerated growth of pre-pubertal obese children. Pre-pubertal obese children are taller than their peers, often start puberty earlier and show earlier maturation of the GP, which may be also associated with loss of the pubertal growth spurt (Shalitin \& Kiess 2017) and final short stature.

To conclude, this study clearly shows that sex hormones limit the efficacy of CUG in pubertal male rats. For the first time, we describe a crosstalk between leptin and aromatase in chondrocytes. Re-feeding was associated with an increase in leptin level, augmented aromatase mRNA expression and protein content, and augmented leptin and estrogen receptors gene expression. Testosterone itself was also increased by re-feeding, as the animals were already old enough. The increase in aromatase expression enhanced the aromatization process of testosterone to estrogen, increased locally produced estrogen then bound to its receptors (also increased), enhancing the senescent decline in the GP chondrocyte proliferation rate, reducing GP height and leading to incomplete CUG. Our results are also supported by a recent study showing a significant higher longitudinal growth rate in animals treated with leptin + estrogen receptor inhibitor compared to leptintreated group, indicating that the concurrent increase in estrogen levels during leptin treatment antagonizes the growth-promoting actions of leptin (Turner 2017).

Identifying factors that limit CUG may open new areas for research and pave the way to improved and new treatment modalities.

\section{Limitations of the study}

The limitations of the study include the fact that we could not follow the changes in the bones in each animal during the experiment, as we do not have access to in vivo CT scan. Additional limitations are the lack of data on aromatase activity and on serum and local estrogen levels. The commercially available estradiol ELISA kit was not sensitive enough to identify the low levels of estradiol in a reliable manner. In addition, owing to the very low level of expression, we could not detect changes in aromatase protein levels in ATDC5 cells after 4 days of differentiation. Other limitations include the small sample size in each group as well as the use of an animal model instead of children, due to ethical considerations.

\section{Supplementary data}

This is linked to the online version of the paper at https://doi.org/10.1530/ JOE-18-0028.

\section{Declaration of interest}

The authors declare that there is no conflict of interest that could be perceived as prejudicing the impartiality of the research reported.

\section{Funding}

This research did not receive any specific grant from any funding agency in the public, commercial or not-for-profit sector.

\section{Author contribution statement}

All authors contributed to study design and have approved the final version of manuscript. M.M. contributed to conduct the study. M M and G-G Y contributed to data collection, data analysis and manuscript drafting and revision. M M, G-G Y, M P and R S contributed to data interpretation.

\section{Acknowledgments}

This work was performed in partial fulfillment of the requirements for a PhD degree of Majdi Masarwi, Sackler Faculty of Medicine, Tel Aviv University, Israel. The authors are grateful to Dr Kristy A Brown (NBCF 
Mavis Robertson Fellow Head, Metabolism and Cancer Laboratory, Hudson Institute of Medical Research, Clayton, Australia) for providing the pGL3 promoter II/1.3, plasmid, and Dr Rina Rosin-Arbesfeld (Department of Clinical Microbiology and Immunology, Sackler Faculty of Medicine, Tel Aviv University, Tel Aviv, Israel) for the pRL-CMV-Renilla plasmid. We also thank Dr Tsaffrir Zor (Department of Biochemistry and Molecular Biology, Life Sciences Faculty, Tel Aviv University, Tel Aviv, Israel) for the PI3K inhibitor Wortmannin. We would also like to acknowledge Gloria Ginzach for English editing of the manuscript.

\section{References}

Aggarwal BB, Kunnumakkara AB, Harikumar KB, Gupta SR, Tharakan ST, Koca C, Dey S \& Sung B 2009 Signal transducer and activator of transcription-3, inflammation, and cancer: how intimate is the relationship? Annals of the New York Academy of Sciences 1171 59-76. (https://doi.org/10.1111/j.1749-6632.2009.04911.x)

Atsumi T, Miwa Y, Kimata K \& Ikawa Y 1990 A chondrogenic cell line derived from a differentiating culture of AT805 teratocarcinoma cells. Cell Differentiation and Development 30 109-116. (https://doi. org/10.1016/0922-3371(90)90079-C)

Attie KM, Ramirez NR, Conte FA, Kaplan SL \& Grumbach MM 1990 The pubertal growth spurt in eight patients with true precocious puberty and growth hormone deficiency: evidence for a direct role of sex steroids. Journal of Clinical Endocrinology and Metabolism 71 975-983. (https://doi.org/10.1210/jcem-71-4-975)

Belgorosky A, Guercio G, Pepe C, Saraco N \& Rivarola MA 2009 Genetic and clinical spectrum of aromatase deficiency in infancy, childhood and adolescence. Hormone Research 72 321-330. (https://doi. org/10.1159/000249159)

Ben-Eliezer M, Phillip M \& Gat-Yablonski G 2007 Leptin regulates chondrogenic differentiation in ATDC5 cell-line through JAK/STAT and MAPK pathways. Endocrine 32 235-244. (https://doi.org/10.1007/ s12020-007-9025-y)

Boersma B, Houwen RH, Blum WF, van Doorn J \& Wit JM 2002 Catch-up growth and endocrine changes in childhood celiac disease. Endocrine changes during catch-up growth. Hormone Research 58 (Supplement 1) 57-65. (https://doi.org/10.1159/000064771)

Carani C, Qin K, Simoni M, Faustini-Fustini M, Serpente S, Boyd J, Korach KS \& Simpson ER 1997 Effect of testosterone and estradiol in a man with aromatase deficiency. New England Journal of Medicine $\mathbf{3 3 7}$ 91-95. (https://doi.org/10.1056/NEJM199707103370204)

Carracedo A \& Pandolfi PP 2008 The PTEN-PI3K pathway: of feedbacks and cross-talks. Oncogene 27 5527-5541. (https://doi.org/10.1038/ onc.2008.247)

Catalano S, Marsico S, Giordano C, Mauro L, Rizza P, Panno ML \& Ando S 2003 Leptin enhances, via AP-1, expression of aromatase in the MCF-7 cell line. Journal of Biological Chemistry $27828668-28676$. (https://doi.org/10.1074/jbc.M301695200)

Chagin AS, Karimian E, Zaman F, Takigawa M, Chrysis D \& Savendahl L 2007 Tamoxifen induces permanent growth arrest through selective induction of apoptosis in growth plate chondrocytes in cultured rat metatarsal bones. Bone $\mathbf{4 0} 1415-1424$. (https://doi.org/10.1016/j. bone.2006.12.066)

Chrysis D, Ritzen EM \& Savendahl L 2003 Growth retardation induced by dexamethasone is associated with increased apoptosis of the growth plate chondrocytes. Journal of Endocrinology 176 331-337. (https://doi. $\operatorname{org} / 10.1677 /$ joe.0.1760331)

Cutler GB Jr 1997 The role of estrogen in bone growth and maturation during childhood and adolescence. Journal of Steroid Biochemistry and Molecular Biology 61 141-144. (https://doi.org/10.1016/S09600760(97)80005-2)

Enjuanes A, Garcia-Giralt N, Supervia A, Nogues X, Ruiz-Gaspa S, Bustamante M, Mellibovsky L, Grinberg D, Balcells S \& Diez-Perez A
2005 Functional analysis of the I.3, I.6, pII and I.4 promoters of CYP19 (aromatase) gene in human osteoblasts and their role in vitamin D and dexamethasone stimulation. European Journal of Endocrinology 153 981-988. (https://doi.org/10.1530/eje.1.02032)

Eshet R, Maor G, Ben Ari T, Ben Eliezer M, Gat-Yablonski G \& Phillip M 2004 The aromatase inhibitor letrozole increases epiphyseal growth plate height and tibial length in peripubertal male mice. Journal of Endocrinology 182 165-172. (https://doi. org/10.1677/joe.0.1820165)

Even-Zohar N, Jacob J, Amariglio N, Rechavi G, Potievsky O, Phillip M \& Gat-Yablonski G 2008 Nutrition-induced catch-up growth increases hypoxia inducible factor 1alpha RNA levels in the growth plate. Bone 42 505-515. (https://doi.org/10.1016/j.bone.2007.10.015)

Farooqi IS, Jebb SA, Langmack G, Lawrence E, Cheetham CH, Prentice AM, Hughes IA, McCamish MA \& O'Rahilly S 1999 Effects of recombinant leptin therapy in a child with congenital leptin deficiency. New England Journal of Medicine 341 879-884. (https://doi. org/10.1056/NEJM199909163411204)

Gat-Yablonski G \& De Luca F 2017 Effect of nutrition on statural growth. Hormone Research in Paediatrics 88 46-62. (https://doi. org/10.1159/000456547)

Gat-Yablonski G \& Phillip M 2008 Leptin and regulation of linear growth. Current Opinion in Clinical Nutrition and Metabolic Care 11 303-308. (https://doi.org/10.1097/MCO.0b013e3282f795cf)

Gat-Yablonski G, Ben-Ari T, Shtaif B, Potievsky O, Moran O, Eshet R, Maor G, Segev Y \& Phillip M 2004 Leptin reverses the inhibitory effect of caloric restriction on longitudinal growth. Endocrinology 145 343-350. (https://doi.org/10.1210/en.2003-0910)

Gat-Yablonski G, Shtaif B \& Phillip M 2007 Leptin stimulates parathyroid hormone related peptide expression in the endochondral growth plate. Journal of Pediatric Endocrinology and Metabolism 20 1215-1222. (https://doi.org/10.1515/JPEM.2007.20.11.1215)

Harada N, Utsumi T \& Takagi Y 1993 Tissue-specific expression of the human aromatase cytochrome P-450 gene by alternative use of multiple exons 1 and promoters, and switching of tissue-specific exons 1 in carcinogenesis. PNAS 90 11312-11316. (https://doi. org/10.1073/pnas.90.23.11312)

Hegyi K, Fulop K, Kovacs K, Toth S \& Falus A 2004 Leptin-induced signal transduction pathways. Cell Biology International 28 159-169. (https:// doi.org/10.1016/j.cellbi.2003.12.003)

Heim M, Frank O, Kampmann G, Sochocky N, Pennimpede T, Fuchs P, Hunziker W, Weber P, Martin I \& Bendik I 2004 The phytoestrogen genistein enhances osteogenesis and represses adipogenic differentiation of human primary bone marrow stromal cells. Endocrinology 145 848-859. (https://doi.org/10.1210/en.2003-1014)

Hero M, Norjavaara E \& Dunkel L 2005 Inhibition of estrogen biosynthesis with a potent aromatase inhibitor increases predicted adult height in boys with idiopathic short stature: a randomized controlled trial. Journal of Clinical Endocrinology and Metabolism 90 6396-6402. (https://doi.org/10.1210/jc.2005-1392)

Hui W, Litherland GJ, Elias MS, Kitson GI, Cawston TE, Rowan AD \& Young DA 2012 Leptin produced by joint white adipose tissue induces cartilage degradation via upregulation and activation of matrix metalloproteinases. Annals of the Rheumatic Diseases 71 455-462. (https://doi.org/10.1136/annrheumdis-2011-200372)

Jeong JH, Jung YK, Kim HJ, Jin JS, Kim HN, Kang SM, Kim SY, van Wijnen AJ, Stein JL, Lian JB, et al. 2010 The gene for aromatase, a rate-limiting enzyme for local estrogen biosynthesis, is a downstream target gene of Runx2 in skeletal tissues. Molecular and Cellular Biology 30 2365-2375. (https://doi.org/10.1128/ MCB.00672-09)

Jung CH \& Kim MS 2013 Molecular mechanisms of central leptin resistance in obesity. Archives of Pharmacal Research 36 201-207. (https://doi.org/10.1007/s12272-013-0020-y)

Kay's SK \& Hindmarsh PC 2006 Catch-up growth: an overview. Pediatric Endocrinology Reviews 3 365-378.
๑) 2018 Society for Endocrinology Published by Bioscientifica Ltd. Printed in Great Britain 
Kishida Y, Hirao M, Tamai N, Nampei A, Fujimoto T, Nakase T, Shimizu N, Yoshikawa H \& Myoui A 2005 Leptin regulates chondrocyte differentiation and matrix maturation during endochondral ossification. Bone 37 607-621. (https://doi.org/10.1016/j. bone.2005.05.009)

Kita K, Kimura T, Nakamura N, Yoshikawa H \& Nakano T 2008 PI3K/ Akt signaling as a key regulatory pathway for chondrocyte terminal differentiation. Genes to Cells 13 839-850. (https://doi.org/10.1111/ j.1365-2443.2008.01209.x)

Kitawaki J, Kusuki I, Koshiba H, Tsukamoto K \& Honjo H 1999 Leptin directly stimulates aromatase activity in human luteinized granulosa cells. Molecular Human Reproduction 5 708-713. (https://doi. org/10.1093/molehr/5.8.708)

Liu L, Wang L, Zheng J \& Tang G 2013 Leptin promotes human endometrial carcinoma cell proliferation by enhancing aromatase (P450arom) expression and estradiol formation. European Journal of Obstetrics and Gynecology and Reproductive 170 198-201. (https://doi. org/10.1016/j.ejogrb.2013.04.004)

Maor G, Rochwerger M, Segev Y \& Phillip M 2002 Leptin acts as a growth factor on the chondrocytes of skeletal growth centers. Journal of Bone and Mineral Research 17 1034-1043. (https://doi.org/10.1359/ jbmr.2002.17.6.1034)

Masarwi M, Gabet Y, Dolkart O, Brosh T, Shamir R, Phillip M \& GatYablonski G 2016 Skeletal effect of casein and whey protein intake during catch-up growth in young male Sprague-Dawley rats. British Journal of Nutrition 116 59-69. (https://doi.org/10.1017/ S0007114516001781)

Mauras N, Gonzalez de Pijem L, Hsiang HY, Desrosiers P, Rapaport R, Schwartz ID, Klein KO, Singh RJ, Miyamoto A \& Bishop K 2008 Anastrozole increases predicted adult height of short adolescent males treated with growth hormone: a randomized, placebocontrolled, multicenter trial for one to three years. Journal of Clinical Endocrinology and Metabolism 93 823-831. (https://doi.org/10.1210/ jc.2007-1559)

Nakajima R, Inada H, Koike T \& Yamano T 2003 Effects of leptin to cultured growth plate chondrocytes. Hormone Research 60 91-98. (https://doi.org/10.1159/000071877)

Nilsson O, Weise M, Landman EB, Meyers JL, Barnes KM \& Baron J 2014 Evidence that estrogen hastens epiphyseal fusion and cessation of longitudinal bone growth by irreversibly depleting the number of resting zone progenitor cells in female rabbits. Endocrinology $\mathbf{1 5 5}$ 2892-2899. (https://doi.org/10.1210/en.2013-2175)

Ohba S, Lanigan TM \& Roessler BJ 2010 Leptin receptor JAK2/STAT3 signaling modulates expression of Frizzled receptors in articular chondrocytes. Osteoarthritis and Cartilage 18 1620-1629. (https://doi. org/10.1016/j.joca.2010.09.006)

Oz OK, Millsaps R, Welch R, Birch J \& Zerwekh JE 2001 Expression of aromatase in the human growth plate. Journal of Molecular Endocrinology 27 249-253. (https://doi.org/10.1677/jme.0.0270249)

Pando R, Shtaif B, Phillip M \& Gat-Yablonski G 2014 A serum component mediates food restriction-induced growth attenuation. Endocrinology 155 932-940. (https://doi.org/10.1210/en.2013-1610)

Phornphutkul C, Wu KY \& Gruppuso PA 2006 The role of insulin in chondrogenesis. Molecular and Cellular Endocrinology 249 107-115. (https://doi.org/10.1016/j.mce.2006.02.002)

Phuong NT, Lim SC, Kim YM \& Kang KW 2014 Aromatase induction in tamoxifen-resistant breast cancer: role of phosphoinositide 3-kinasedependent CREB activation. Cancer Letter 351 91-99. (https://doi. org/10.1016/j.canlet.2014.05.003)

Pino AM, Rodriguez JM, Rios S, Astudillo P, Leiva L, Seitz G, Fernandez M \& Rodriguez JP 2006 Aromatase activity of human mesenchymal stem cells is stimulated by early differentiation, vitamin D and leptin. Journal of Endocrinology 191 715-725. (https://doi.org/10.1677/ joe.1.07026)

Pittenger MF, Mackay AM, Beck SC, Jaiswal RK, Douglas R, Mosca JD, Moorman MA, Simonetti DW, Craig S \& Marshak DR 1999
Multilineage potential of adult human mesenchymal stem cells. Science 284 143-147. (https://doi.org/10.1126/science.284.5411.143)

Prader A, Tanner JM \& von HG 1963 Catch-up growth following illness or starvation. An example of developmental canalization in man Journal of Pediatrics 62 646-659. (https://doi.org/10.1016/S00223476(63)80035-9)

Reseland JE, Syversen U, Bakke I, Qvigstad G, Eide LG, Hjertner O, Gordeladze JO \& Drevon CA 2001 Leptin is expressed in and secreted from primary cultures of human osteoblasts and promotes bone mineralization. Journal of Bone and Mineral Research 16 1426-1433. (https://doi.org/10.1359/jbmr.2001.16.8.1426)

Sakaguchi M, Oka M, Iwasaki T, Fukami Y \& Nishigori C 2012 Role and regulation of STAT3 phosphorylation at Ser727 in melanocytes and melanoma cells. Journal of Investigative Dermatology 132 1877-1885. (https://doi.org/10.1038/jid.2012.45)

Sasano H, Uzuki M, Sawai T, Nagura H, Matsunaga G, Kashimoto O \& Harada N 1997 Aromatase in human bone tissue. Journal of Bone and Mineral Research 12 1416-1423. (https://doi.org/10.1359/ jbmr.1997.12.9.1416)

Schrier L, Ferns SP, Barnes KM, Emons JA, Newman EI, Nilsson O \& Baron J 2006 Depletion of resting zone chondrocytes during growth plate senescence. Journal of Endocrinology 189 27-36. (https://doi. org/10.1677/joe.1.06489)

Schust J, Sperl B, Hollis A, Mayer TU \& Berg T 2006 Stattic: a smallmolecule inhibitor of STAT3 activation and dimerization. Chemistry and Biology 13 1235-1242. (https://doi.org/10.1016/j. chembiol.2006.09.018)

Shalitin S \& Kiess W 2017 Putative effects of obesity on linear growth and puberty. Hormone Research in Paediatrics 88 101-110. (https://doi. org/10.1159/000455968)

Shtaif B, Dror N, Bar-Maisels M, Phillip M \& Gat-Yablonski G 2015 Growth without growth hormone: can growth and differentiation factor 5 be the mediator? Growth Factors 33 309-318. (https://doi.org/ 10.3109/08977194.2015.1082557)

Smith EP, Boyd J, Frank GR, Takahashi H, Cohen RM, Specker B, Williams TC, Lubahn DB \& Korach KS 1994 Estrogen resistance caused by a mutation in the estrogen-receptor gene in a man. New England Journal of Medicine 331 1056-1061. (https://doi.org/10.1056/ NEJM199410203311604)

Starkman BG, Cravero JD, Delcarlo M \& Loeser RF 2005 IGF-I stimulation of proteoglycan synthesis by chondrocytes requires activation of the PI3-kinase pathway but not ERK MAPK. Biochemical Journal 389 723-729. (https://doi.org/10.1042/BJ20041636)

Stevens DA \& Williams GR 1999 Hormone regulation of chondrocyte differentiation and endochondral bone formation. Molecular and Cellular Endocrinology 151 195-204. (https://doi.org/10.1016/S03037207(99)00037-4)

Tan T, Wang L \& Wang B 2015 Collagen and prostaglandin E(2) regulate aromatase expression through the PI3K/AKT/IKK and the MAP kinase pathways in adipose stromal cells. Molecular Medicine Reports 12 4766-4772. (https://doi.org/10.3892/mmr.2015.3901)

Turner RT, Kalra SP, Wong CP, Philbrick KA, Lindenmaier LB, Boghossian S \& Iwaniec UT 2013 Peripheral leptin regulates bone formation. Journal of Bone and Mineral Research 28 22-34. (https://doi. org/10.1002/jbmr.1734)

Turner RT, Philbrick KA, Kuah AF, Branscum AJ, Iwaniec UT 2017 Role of estrogen receptor signaling in skeletal response to leptin in female ob/ob mice. Journal of Endcorinology 233 357-367. (https://doi. org/10.1530/JOE-17-0103)

Wang SJ, Li XF, Jiang LS \& Dai LY 2012a Estrogen stimulates leptin receptor expression in ATDC5 cells via the estrogen receptor and extracellular signal-regulated kinase pathways. Journal of Endocrinology 213 163-172. (https://doi.org/10.1530/ JOE-11-0353

Wang SJ, Li XF, Jiang LS \& Dai LY $2012 b$ Leptin regulates estrogen receptor gene expression in ATDC5 cells through the extracellular 
signal regulated kinase signaling pathway. Journal of Cellular Biochemistry 113 1323-1332. (https://doi.org/10.1002/jcb.24005)

Wegiel B, Bjartell A, Culig Z \& Persson JL 2008 Interleukin-6 activates PI3K/Akt pathway and regulates cyclin A1 to promote prostate cancer cell survival. International Journal of Cancer 122 1521-1529. (https:// doi.org/10.1002/ijc.23261)

Weise M, De-Levi S, Barnes KM, Gafni RI, Abad V \& Baron J 2001 Effects of estrogen on growth plate senescence and epiphyseal fusion. PNAS 98 6871-6876. (https://doi.org/10.1073/pnas.121180498)

Wickman S, Sipila I, Ankarberg-Lindgren C, Norjavaara E \& Dunkel L 2001 A specific aromatase inhibitor and potential increase in adult height in boys with delayed puberty: a randomised controlled trial. Lancet 357 1743-1748. (https://doi.org/10.1016/S01406736(00)04895-9)
Wit JM, Hero M \& Nunez SB 2011 Aromatase inhibitors in pediatrics. Nature Reviews Endocrinology 8 135-147. (https://doi.org/10.1038/ nrendo.2011.161)

Yang R \& Barouch LA 2007 Leptin signaling and obesity: cardiovascular consequences. Circulation Research 101 545-559. (https://doi. org/10.1161/CIRCRESAHA.107.156596)

Yang G, Zhu L, Hou N, Lan Y, Wu XM, Zhou B, Teng Y \& Yang X 2014 Osteogenic fate of hypertrophic chondrocytes. Cell Research 24 1266-1269. (https://doi.org/10.1038/cr.2014.111)

Zhou X, von der Mark K, Henry S, Norton W, Adams H \& de Crombrugghe B 2014 Chondrocytes transdifferentiate into osteoblasts in endochondral bone during development, postnatal growth and fracture healing in mice. PLoS Genetics 10 e1004820. (https://doi. org/10.1371/journal.pgen.1004820)

Received in final form 11 March 2018

Accepted 3 April 2018

Accepted Preprint published online 3 April 2018 